\title{
FORMING OF CRUDE OIL MIXTURES WITH IN CREASED YIELD OF TARGET FRACTIONS
}

\author{
Olena Tertyshna ${ }^{1, *}$, Vitalina Martynenko ${ }^{1}, K$ ostyantyn Zamikula, \\ Petro Topilnytskyy², Yurii Holych ${ }^{3}$
}

https:

\begin{abstract}
Researches results of 5 samples of crude oil have been analyzed and generalized. The relationship between component, structural-group composition and physico-chemical properties have been determined to classify crude oil reliably and rapidly. Compounding and sequence of crude oil mixture forming have been developed to provide the maximum yield of target fractions. These principles are based on combination of simulation method, cluster and statistic analyses. The expediency of the proposed forming method has been confirmed experimentally.
\end{abstract}

Keywords: crude oil, mixture, compounding, simulation, target fraction.

\section{Introduction}

The current trend of crude oil processing determines the importance of studying the impact of raw materials and basic parameters of the fractionation on the process. The determined regularities allow to intensify the refining and facilitate the increase of the target fractions selection depth, as well as fractioning efficiency at significant changes in crude oil composition.

One of the promising ways to improve the oil refining is scientifically based approach to the preparation of raw materials. The multicomponent crude oil mixtures are widely used as raw material.

When determining the potential content of target fractions in such mixtures an additivity rule is usually applied [1]. True boiling point (TBP) curves of the mixture components are divided into narrow fractions,

\footnotetext{
${ }^{1}$ State Higher Educational Institution "Ukrainian State Chemical Technological University"

8, Gagarin Ave., 49605 Dnipro, Ukraine

${ }^{2}$ Lviv Polytechnic National University, 12, S. Bandera St., 79013 Lviv, Ukraine

${ }^{3}$ JSC "Ukrtatnafta", 3 Svishtovskaya St., 39610 Kremenchuk, Poltava region, Ukraine

T_elena2000@bigmir.net

(C) Tertyshna O., Martynenko V., Zamikula K., Topilnytskyy P., Holych Yu., 2017
}

which are then combined into target products in proportion to the components shares in the mixture. This prediction often gives large errors while identifying the potential target factions and consequently reduces the depth of recovery.

It is known that the total yield of light oil products is higher while refining the crude oil mixture of different nature with the optimal ratio compared with separate refining [2]. In this connection it is of interest to determine the optimum ratio of the components that will ensure more efficient use of resources of petroleum origin.

Experimental determination of the components optimal ratio is labour- and time-consuming. In the industry, different types of crude oil are often mixed randomly. The main criterion for this raw material is a potential content of target fractions and agreement of their characteristics with the standard specifications for petroleum products. The problem of refining intensification can be solved if crude oil is considered as an oil dispersed system.

The way of refining modification is mixing of raw flows, different by chemical nature. In this case the mixture properties are changed non-additively and the components ratio, under which the yield of a desired product exceeds the additive one, may be calculated.

The aim of this work was to identify the relationship between the component composition and crude oil properties to determine the sequence of compounds forming and obtain maximum yield of kerosene fraction (413-513 K).

\section{Experimental}

The following tasks were set: 1) analysis and generalization of investigation results about composition and properties of crude oil and its components; 2) determination of relationship between component, hydrocarbon, structural-group compositions, and physicochemical characteristics to classify crude oil reliably and rapidly; 3 ) development of compounding and sequence of crude oil mixtures forming that provide maximum yield of target fraction based on a combination of mathematical modelling, cluster and statistical analyses. 
Physico-chemical properties of crude oil samples

\begin{tabular}{|c|c|c|c|c|c|c|c|c|c|c|c|}
\hline $\begin{array}{l}\overline{\bar{\sigma}} \\
\overline{0} \\
\overline{\tilde{J}} \\
\end{array}$ & 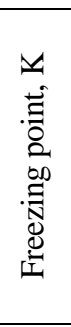 & 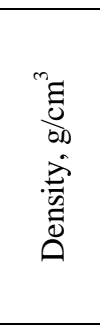 & 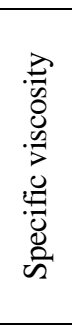 & 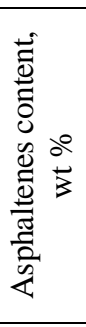 & 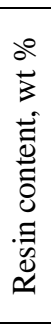 & 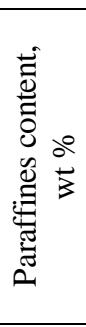 & 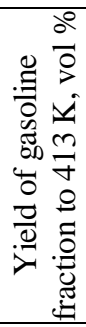 & 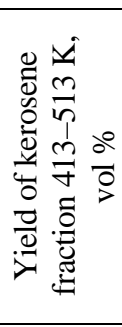 & 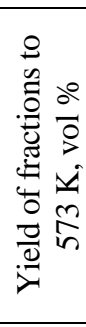 & 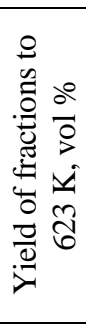 & 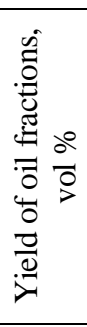 \\
\hline Blend 03.16 & 262 & 0.7966 & 1.0 & 0.42 & 2 & 2.00 & 30.57 & 24.15 & 65.78 & 74.71 & 19.9 \\
\hline UN 03.16 & 266 & 0.8498 & 1.3 & 0.43 & 28 & 2.31 & 22.67 & 14.88 & 48.32 & 55.51 & 39.5 \\
\hline ZUN 03.16 & 286 & 0.8422 & 1.2 & 0.34 & 21 & 1.60 & 18.77 & 15.94 & 45.19 & 54.85 & 39.8 \\
\hline Blend 09.15 & 259 & 0.7959 & 1.24 & 0.42 & 4 & 2.30 & 30.19 & 23.02 & 65.57 & 74.55 & 20.2 \\
\hline UN 09.15 & 263 & 0.8428 & 1.2 & 0.43 & 23 & 2.30 & 18.53 & 17.65 & 48.22 & 56.06 & 37.3 \\
\hline
\end{tabular}

The investigation objects were 5 samples of crude oil processed by Ukrainian refineries: oil from WestUkrainian deposits - ZUN 03.16, mixture of oils from Ukrainian deposits - UN 03.16, UN 09.15 and Kazakh oils Blend 03.16 and Blend 09.15. The figures refer to the oil sampling timeline - a month and a year, respectively. Physico-chemical properties of crude oil samples are shown in Table 1.Potential amount of crude oil fractions was determined according to the standards [3] and TBP curve was plotted. Physico-chemical properties were analyzed according to [4-7]. Asphaltenes were precipitated from reduced crude by 40 -fold excess of petroleum ether (313-343 K). Asphalt-free oil was divided into oils and resins using column chromatography with solvents: petroleum ether (313-343 K) : carbon tetrachloride (3:1) and benzene : isopropyl alcohol (1:1).

At the first stage the samples were classified using cluster analysis. Crude oils were grouped according to the closeness of their physico-chemical properties using complete association rule; proximity index was estimated relative to Euclidean distance $[8,9]$.

Due to the dissimilarity of physico-chemical indices it was necessary to standardize them in accordance with formula (1):

$$
z=\frac{(x-\bar{x})}{\left(x_{\max }-x_{\min }\right)}
$$

where $z$ - standard physico-chemical index; $\bar{x}$ - average deviation from $x ; x_{\max }-$ maximum value of $x ; x_{\min }-$ minimum value of $x$.

Real crude is irregularly boiled, at different temperatures narrow fractions are boiled with different intensity. Rectificate yield depending on temperature is represented as a continuous function $G=f(t)$, which was differentiated relative to argument. The dependence $\frac{d^{2} G}{d t^{2}}$ was denominated as a boiling rate (BR) [10-11]. BR curves more completely characterize the behavior of crude during boiling compared with TBP curves. Positive value of BR means acceleration of boiling process whereas the negative value - its deceleration. Therefore, we were able to estimate the relative content of narrow fractions in crude oil and to determine the temperature ranges of mixture energy-optimal separation via rectification (areas of BR local minima and maxima).

\section{Results and Discussion}

On the basis of data from Table 1, using STATISTICA 10.0 package and hierarchical cluster analysis we created vertical dendrogram relative to density, viscosity, freezing point, fractional composition, and content of resins and paraffins (Fig. 1).

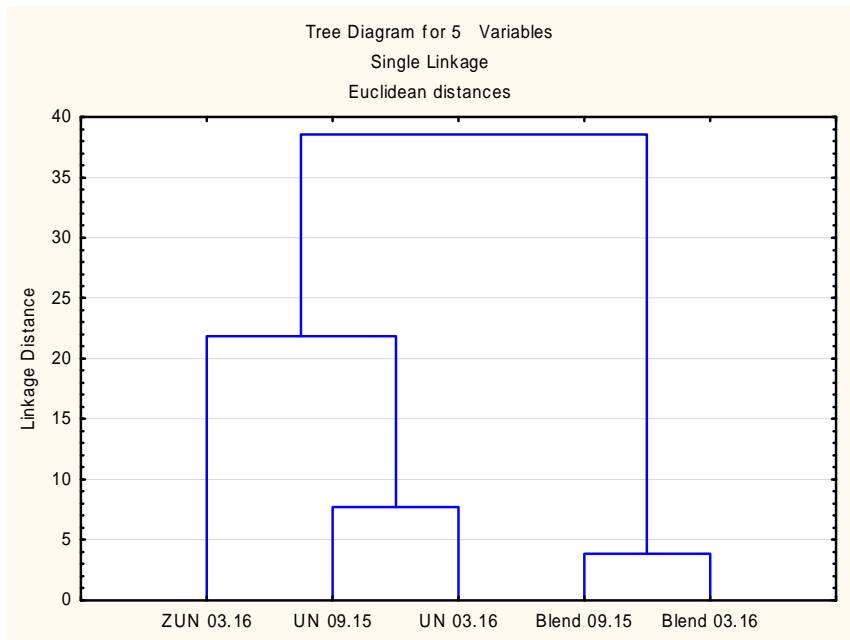

Fig. 1. Vertical dendrogram of crude oil classification 
According to the analysis results all samples are divided into three clusters. The first one unites UN 03.16 and UN 09.15 oils, which have similar parameters (Table 1) with the distance of 0.35 . The second cluster is formed by combination of the first cluster with ZUN 03.16. The distance is maximum (1.0) due to the considerable difference in freezing point, contents of paraffins, resins, asphaltenes, and potential content of gasoline fractions. The third cluster unites crude oils Blend 03.16 and Blend 09.15 with minimum distance of 0.13 . It is recommended to mix oils which are united in the clusters with minimum distance, i.e. to form two-component system Blend 03.16 and Blend 09.15. To form threecomponent system we use ZUN 03.16, UN 03.16 and UN 09.15. Crude oil mixtures formed according to the mentioned recommendations maintain their potential and physico-chemical properties while mixing; this is important for refineries.

On the basis of TBP curves of Blend 03.16 and Blend 09.15 we calculate the second derivatives and plot BR curves with $1 \mathrm{wt} \%$ step (Fig. 2). Calculations and optimization of the component composition were performed using Mathcad package.

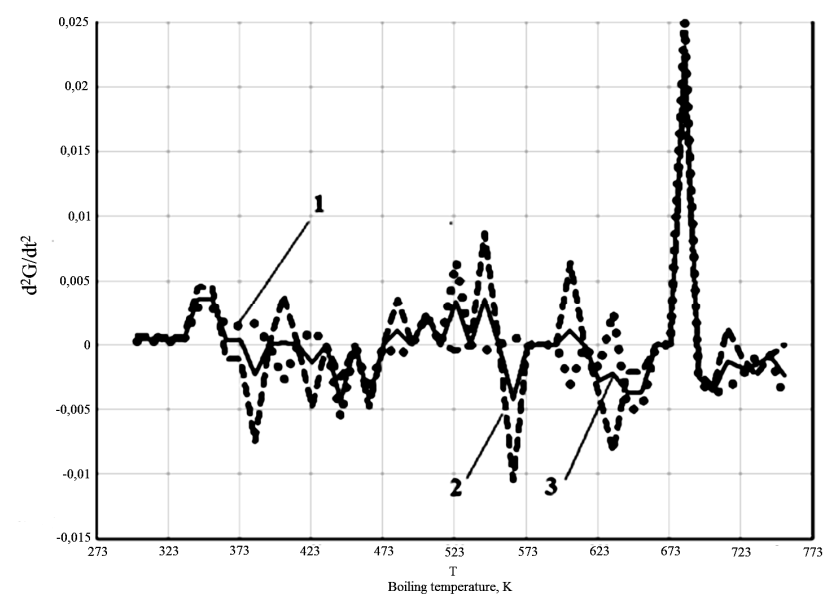

Fig. 2. BR vs. boiling temperatures for Blend 03.16 (1); Blend 09.15 (2) and their optimum mixture (3)

The addition of oil-intensifier to the basic oil decreases the boiling rate within the temperature range of target fraction (413-513 K) and increases its yield with regard to the additively calculated one. The componentintensifier is determined using $\varphi(B R)$ potential calculated by formula (2). Zero value corresponds to the constant boiling rate:

$$
\varphi(B R)=\frac{\int_{t_{1}}^{t_{2}} B R(t) d t \text { at } B R(t)>0}{\int_{t_{1}}^{t_{2}} B R(t) d t \text { at } B R(t)<0}
$$

If $\varphi(B R)<1$, then target fraction is susceptible to boiling rate deceleration, if $\varphi(B R)>1$ - to acceleration. To obtain the maximum yield of target fractions from the oil mixture with different BR, the crude with lower $\varphi(B R)$ is taken as the intensifier.

Linear interpolation of the results is taken as an additivity line. Deviation from additivity is determined as a difference between $v_{B R}$ and $v_{a d}$ :

$$
\begin{gathered}
v_{a d}=\sum v_{B R i} \cdot \omega_{i} \\
v_{B R}=\int_{t_{1}}^{t_{2}} B R(t) d t(\text { at } B R(t)>0)- \\
-\int_{t_{1}^{2}}^{t_{2}} B R(t) d t(\text { at } B R(t)<0)
\end{gathered}
$$

where $v_{a d}$ - calculated average boiling rate of the mixture according to the additivity rule; $v_{B R i}-$ calculated average boiling rate of $i$-crude fractions according to BR; $v_{B R}$ calculated average boiling rate of the mixture according to BR; $\omega_{i}$ - weight part of $i$-crude in the mixture.

The optimal composition of the mixture with maximum yield of target product is calculated using developed program product. The results are presented in Fig. 3.

The area of maximum positive deviation (Max, Fig. 3) was found to be the optimum one. When using the mixture corresponding to this area, the yield of target fraction is the highest. The area of maximum negative deviation (Min, Fig. 3) corresponds to the mixture, the use of which results in the decrease of target fraction yield. For the mixture Blend 03.16 and Blend 09.15 the optimal ratio of the components was found to be 49:51. Blend 09.15 is the process intensifier (boiling potential is 0.493), which is added to the basic crude Blend 03.16 (boiling potential is 0.536 ).

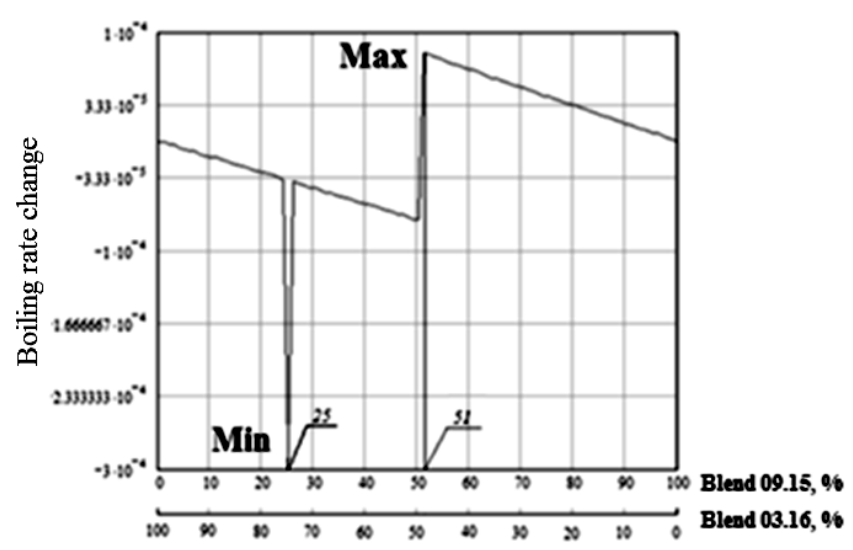

Fig. 3. Graphical interpretation of the calculated boiling rate deviation for two-component mixture from additive values and determination of the mixture optimal composition 
When using the optimal mixture the increase in kerosene fraction yield is provided by redistribution a part of 513-533 K and 593-613 K fractions (Fig. 2) and deceleration of boiling rate of $413-513 \mathrm{~K}$ target fraction within the mentioned temperature range. The results of two-component (49:51) mixture distillation (Fig. 3) confirm the increase in target fraction yield by $3.5 \mathrm{vol} \%$ compared with additive yield. The distillation of the mixture with the ratio of 75:25 decreases the kerosene fraction yield by $0.8 \mathrm{vol} \%$.

Deviation of boiling rate from the calculated value while forming three-component mixture (UN 03.16, ZUN 03.16 and UN 09.15) is represented in Fig. 4.

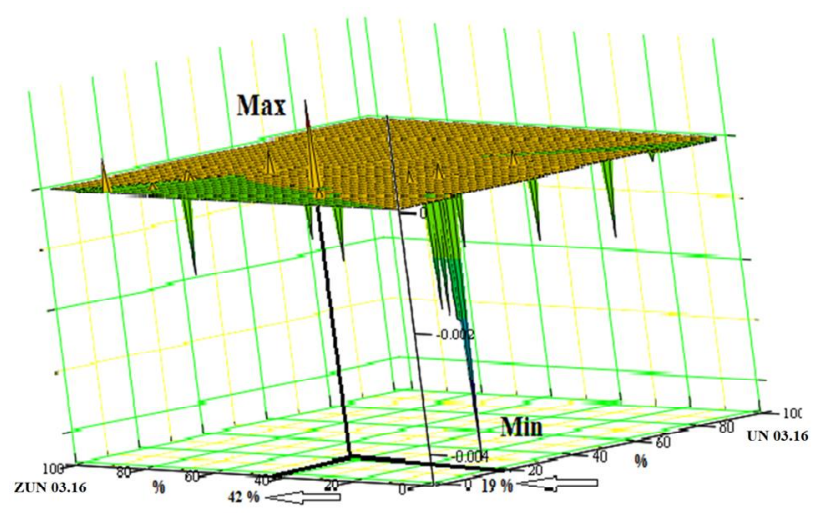

Fig. 4. Graphical interpretation of the calculated boiling rate deviation for three-component mixture from additive values and determination of the mixture optimal composition

For UN 03.16, ZUN 03.16 and UN 09.15 mixture the most optimal ratio was found to be 19:41:40 and the less optimal - 18:2:80 (Fig. 4).

Since the cluster analysis shows the closeness of UN 03.16 and UN 09.15 properties, the crude-intensifier UN 09.15 (boiling potential is 0.333) is added to UN 03.16 (boiling potential is 0.697). Then required quantity of ZUN 03.16 is added.

When distilling three-component mixture with the calculated ratio of 19:41:40, the kerosene fraction yield increases by $1.6 \%$ compared with the additive one; when the ratio is $18: 2: 80$, the yield decreases by $1.9 \mathrm{vol} \%$.

\section{Conclusions}

Physico-chemical parameters of five samples of crude oil were analyzed. The samples were grouped into clusters with regard to their similarity, which was estimated by distance value 0.13 for two-component mixture and 1.0 - for three-component mixtures.

Two- and three-component mixtures were formed, the sequence of component mixing and optimal ratio were determined using boiling rate curves and mathematical modelling.

The increase in kerosene fraction yield by 3.5 vol \% (two-component mixture) and 1.6 vol \% (threecomponent mixture) compared with additive values were confirmed by the experiments.

\section{References}

[1] Evdokimov I., Losev A., Fesan A.: Burenie Nefti, 2012, 1, 27.

[2] Ovcharov S., Pikalov G., Pikaloc S.: Khim. Technol. Topliv Masel, 2005, 1, 37.

[3] ASTM D 86-05 Standard test method for distillation of petroleum products at atmospheric pressure EN ISO 3405:2000 Petroleum products - Determination of distillation characteristics at atmospheric pressure (ISO 3405:2000).

[4] ASTM D 1298-99e2 Standard test method for density, relative density (specific gravity), or API gravity of crude petroleum and liquid petroleum products by hydrometer method EN ISO 3675:1998 Crude petroleum and liquid petroleum products Laboratory determination of density - Hydrometer method (ISO 3675:1998).

[5] ASTM D 4052-09 Standard Test Method for Density, Relative Density, and API Gravity of Liquids by Digital Density Meter.

[6] ASTM D 445-04e1 Standard test method for kinematic viscosity of transparent and opaque liquids (the calculation of dynamic viscosity).

[7] ASTM D97-17 Standard Test Method for Pour Point of Petroleum Products. (ISO 3016:1994 Petroleum Products Determination of Pour Point).

[8] Eremenko V., Pereidenko A.: Vost. Evr. Zh. Perdovykh Technol., 2010, 43, 40.

[9] Umanets T.: Zagalna Teoria Statystyky. Znannia, Kyiv 2006.

[10] Tertyshna O.: VIII Int. Conf. "Advance in Petroleum and Gas Chemistry and Petrochemistry”, Ukraine, Lviv 2016, 24.

[11] Ovcharov S., Pikalov G., Pikalov S., Ovcharova A.: Sbornik Nauchn. Trudov SevKavNIPIgaza, 2004, 41, 319.

Received: January 10, 2017 / Revised: J anuary 22, 2017 / Accepted: March 23, 2017

\section{ФОРМУВАННЯ НАФТОВИХ СУМШШЕЙ З ПІДВИЩЕНИМ ВИХОДОМ ЦІЛЬОВИХ ФРАКЦІЙ}

Анотація. Проаналізовано $i$ узагальнено результати дослідження компонентного складу $i$ фізико-хімічних властивостей 5 зразків нафти. Виявлено та встановлено взаємозв'язок між компонентним, структурно-груповим складом та фізико-хімічними характеристиками з метою експресної та достовірної класифікації нафти. Розроблено принции визначення рещептури та порядку формування нафтових сумішей, які забезпечують максимальний вихід цільових фракцій, що базується на поєднанні методів моделювання, кластерного та статистичного аналізів. Експериментально підтверджено доцільність запропонованого способу формування нафтових сумімей.

Ключові слова: нафта, суміш, компаундування, моделювання, ичільова фракиія. 